\title{
Measurement of Ultraviolet Radiation from Welding Arcs
}

\author{
Tsutomu OKUNO
}

\author{
National Institute of Industrial Health, \\ 21-1, Nagao 6-chome, Tama-ku, Kawasaki 214, Japan
}

(Received February 27, 1987 and in revised form May 11, 1987)

\begin{abstract}
It is well khown that welding arcs emit intense ultraviolet radiation and those who conduct welding operations or work nearby are exposed to the radiation and often suffer injuries. It is desirable to evaluate the ultraviolet radiation from the viewpoint of industrial health. But, there have been few quantitative studies of this radiation.

We determined the ultraviolet effective irradiance, based approximately on the recommendation of the American Conference of Governmental Industrial Hygienists, for 14 different arc-welding operations commonly conducted in the workplaces. For most of them, the ultraviolet effective irradiance was at a hazardous level for both those who conduct welding operations and those who work near it. In comparing those welding operations, we found that the ultraviolet radiation hazards vary widely with welding operations. They increase with the diameter of wire, arc current and arc voltage when the type of welding method and the chemical composition of the welding materials are the same.
\end{abstract}

Key words: Ultraviolet radiation-Effective irradiance-Relative spectral effectiveness-Welding-Arc

\section{INTRODUCTION}

It is well known that exposure to ultraviolet radiation produces adverse effects: conjunctivitis and keratitis in eyes and erythema in the skin. In the workplace, there are various sources of ultraviolet radiation, such as welding arcs, germicidal lamps, photocopying machines and discharge lamps for chemical industry. Workers exposed to this radiation often suffer injuries. It is desirable to evaluate the ultraviolet radiation of each source from the viewpoint of industrial health. But, there have been few quantitative studies of such ultraviolet radiation.

At present, welding arcs are the most important sources, because the number of arc-welders and those who work nearby is very large and the rate of injuries by ultraviolet radiation among these workers is estimated to be as high as 80 90\% .1) There are various arc-welding methods. Moreover, even for the same arc-welding method, many factors affect the radiation, such as types of base metal and wire, arc voltage, arc current, arc length etc. Normally, the intensity 
and spectral distribution of the emitted optical radiation vary widely with types of arc-welding method and the other parameters, and its degree of harmfulness also varies. ${ }^{1-4)}$ It is useful for the protection of workers against ultraviolet radiation damage to determine the ultraviolet radiation level of each type of arc-welding method under various conditions and to determine which methods and conditions have a significant influence on the ultraviolet radiation. To do this, it is necessary to measure ultraviolet radiation for as many types of arcwelding method and under as many different conditions as possible.

Ultraviolet radiation levels are represented as ultraviolet effective irradiance (UEI). This is the integrated spectral irradiance weighted against ultraviolet relative spectral effectiveness (URSE, action spectrum). It indicates the degree of harmfulness of ultraviolet radiation as a function of wavelength. Different URSE can be defined depending on the radiation damage in question, for example, keratitis and erythema. For the same damage, moreover, different URSE may be derived from different biological data. UEIs based on different URSE are

Table 1. Welding conditions

\begin{tabular}{|c|c|c|c|c|c|}
\hline No. & Welding process & $\begin{array}{c}\text { Wire } \\
\text { JIS } \\
\text { diameter }\end{array}$ & $\begin{array}{l}\text { Base } \\
\text { metal } \\
(\text { JIS })\end{array}$ & $\begin{array}{l}\text { Current, } \\
\text { Voltage, } \\
\text { Polarity }\end{array}$ & $\begin{array}{l}\text { Shielding } \\
\text { gas } \\
\text { Flow rate }\end{array}$ \\
\hline $1 \mathrm{a}$ & $\begin{array}{l}\text { Shielded metal arc welding, } \\
\text { ilmenite type }\end{array}$ & $\begin{array}{l}\mathrm{D} 4301 \\
2.6 \mathrm{~mm}\end{array}$ & $\begin{array}{l}\text { Mild steel } \\
\text { (SS41) }\end{array}$ & $\begin{array}{l}\text { 70A, } 20 \mathrm{~V} \\
\mathrm{AC}\end{array}$ & unnecessary \\
\hline $1 b$ & $\begin{array}{l}\text { Shielded metal arc welding, } \\
\text { ilmenite type }\end{array}$ & $\begin{array}{l}\text { D } 4301 \\
4.0 \mathrm{~mm}\end{array}$ & $\begin{array}{l}\text { Mild steel } \\
\text { (SS41) }\end{array}$ & $\begin{array}{l}170 \mathrm{~A}, 30 \mathrm{~V} \\
\mathrm{AC}\end{array}$ & unnecessary \\
\hline $1 \mathrm{c}$ & $\begin{array}{l}\text { Shielded metal arc welding, } \\
\text { ilmenite type }\end{array}$ & $\begin{array}{l}\mathrm{D} 4301 \\
8.0 \mathrm{~mm}\end{array}$ & $\begin{array}{l}\text { Mild steel } \\
\text { (SS41) }\end{array}$ & $\begin{array}{l}400 \mathrm{~A}, 36 \mathrm{~V} \\
\mathrm{AC}\end{array}$ & unnecessary \\
\hline $2 b$ & $\begin{array}{l}\text { Shielded metal arc welding, } \\
\text { low-hydrogen type }\end{array}$ & $\begin{array}{l}\mathrm{D} 4316 \\
4.0 \mathrm{~mm}\end{array}$ & $\begin{array}{l}\text { Mild steel } \\
\text { (SS41) }\end{array}$ & $\begin{array}{l}170 \mathrm{~A}, 23 \mathrm{~V} \\
\mathrm{AC}\end{array}$ & unnecessary \\
\hline $2 c$ & $\begin{array}{l}\text { Shielded metal arc welding, } \\
\text { low-hydrogen type }\end{array}$ & $\begin{array}{l}\mathrm{D} 4316 \\
8.0 \mathrm{~mm}\end{array}$ & $\begin{array}{l}\text { Mild steel } \\
\text { (SS41) }\end{array}$ & $\begin{array}{l}400 \mathrm{~A}, 32 \mathrm{~V} \\
\mathrm{AC}\end{array}$ & unnecessary \\
\hline 3 & $\begin{array}{l}\mathrm{CO}_{2} \text { gas shielded arc welding } \\
\left(\mathrm{CO}_{2} \text { welding }\right) \text { with solid wire }\end{array}$ & $\begin{array}{l}\text { YGW12 } \\
1.2 \mathrm{~mm}\end{array}$ & $\begin{array}{l}\text { Mild steel } \\
\text { (SS41) }\end{array}$ & $\begin{array}{l}150 \mathrm{~A}, 23 \mathrm{~V} \\
\mathrm{DC}(+)\end{array}$ & $\begin{array}{l}\mathrm{CO}_{2} \text { gas } \\
201 / \mathrm{min}\end{array}$ \\
\hline 4 & $\begin{array}{l}\text { Metal active gas shielded } \\
\text { arc welding (MAG welding) }\end{array}$ & $\begin{array}{l}\text { YGW12 } \\
1.2 \mathrm{~mm}\end{array}$ & $\begin{array}{l}\text { Mild steel } \\
\text { (SS41) }\end{array}$ & $\begin{array}{l}150 \mathrm{~A}, 21 \mathrm{~V} \\
\mathrm{DC}(+)\end{array}$ & $\begin{array}{l}\mathrm{Ar}: \mathrm{CO}_{2}=5: 1 \\
201 / \mathrm{min}\end{array}$ \\
\hline 5 & $\begin{array}{l}\mathrm{CO}_{2} \text { gas shielded arc welding } \\
\left(\mathrm{CO}_{2} \text { welding }\right) \text { with solid wire }\end{array}$ & $\begin{array}{l}\text { YGW11 } \\
1.6 \mathrm{~mm}\end{array}$ & $\begin{array}{l}\text { Mild steel } \\
\text { (SS41) }\end{array}$ & $\begin{array}{l}300 \mathrm{~A}, 35 \mathrm{~V} \\
\mathrm{DC}(+)\end{array}$ & $\begin{array}{l}\mathrm{CO}_{2} \text { gas } \\
201 / \mathrm{min}\end{array}$ \\
\hline 6 & $\begin{array}{l}\text { Metal active gas shielded } \\
\text { arc welding (MAG welding) }\end{array}$ & $\begin{array}{l}\text { YGW11 } \\
1.6 \mathrm{~mm}\end{array}$ & $\begin{array}{l}\text { Mild steel } \\
\text { (SS41) }\end{array}$ & $\begin{array}{l}300 \mathrm{~A}, 33 \mathrm{~V} \\
\mathrm{DC}(+)\end{array}$ & $\begin{array}{l}\mathrm{Ar}: \mathrm{CO}_{2}=5: 1 \\
201 / \mathrm{min}\end{array}$ \\
\hline 7 & $\begin{array}{l}\mathrm{CO}_{2} \text { gas shielded arc welding } \\
\left(\mathrm{CO}_{2} \text { welding }\right) \text { with flux-cored } \\
\text { wire }\end{array}$ & $\begin{array}{l}\text { YFW24 } \\
1.2 \mathrm{~mm}\end{array}$ & $\begin{array}{l}\text { Mild steel } \\
(\text { SS41) }\end{array}$ & $\begin{array}{l}300 \mathrm{~A}, 35 \mathrm{~V} \\
\mathrm{DC}(+)\end{array}$ & $\begin{array}{l}\mathrm{CO}_{2} \text { gas } \\
201 / \mathrm{min}\end{array}$ \\
\hline 8 & $\begin{array}{l}\mathrm{CO}_{2} \text { gas shielded arc welding } \\
\left(\mathrm{CO}_{2} \text { welding }\right) \text { with flux-cored } \\
\text { wire }\end{array}$ & $\begin{array}{l}\text { E308TI } \\
1.2 \mathrm{~mm}\end{array}$ & $\begin{array}{l}\text { Stainless } \\
\text { steel } \\
\text { (SUS304) }\end{array}$ & $\begin{array}{l}270 A, 35 V \\
\mathrm{DC}(+)\end{array}$ & $\begin{array}{l}\mathrm{CO}_{2} \text { gas } \\
201 / \mathrm{min}\end{array}$ \\
\hline 9 & $\begin{array}{l}\text { Metal inert gas shielded arc } \\
\text { welding (MIG welding) }\end{array}$ & $\begin{array}{l}\text { A5183-WY } \\
1.6 \mathrm{~mm}\end{array}$ & $\begin{array}{l}\text { Aluminum } \\
\text { (A5083) }\end{array}$ & $\begin{array}{l}250 \mathrm{~A}, 27 \mathrm{~V} \\
\mathrm{DC}(+)\end{array}$ & $\begin{array}{l}\text { Ar gas } \\
201 / \mathrm{min}\end{array}$ \\
\hline 10 & $\begin{array}{l}\text { Tungsten inert gas shielded } \\
\text { arc welding (TIG welding) }\end{array}$ & not used & $\begin{array}{l}\text { Stainless } \\
\text { steel } \\
\text { (SUS304) }\end{array}$ & $\begin{array}{l}100 \mathrm{~A}, 13 \mathrm{~V} \\
\mathrm{DC}(-)\end{array}$ & $\begin{array}{l}\text { Ar gas } \\
101 / \mathrm{min}\end{array}$ \\
\hline 12 & Self-shelded arc welding & $\begin{array}{l}\text { YFW12 } \\
3.2 \mathrm{~mm}\end{array}$ & $\begin{array}{l}\text { Mild steel } \\
\text { (SS41) }\end{array}$ & $\begin{array}{l}400 \mathrm{~A}, 25 \mathrm{~V} \\
\mathrm{AC}\end{array}$ & unnecessary \\
\hline
\end{tabular}

JIS is Japanese Industrial Standards. 
different quantities by definition; among these, direct comparison is meaningless and the transformation is quite difficult. Therefore, the appropriate selection of the URSE is an important problem in the evaluation of ultraviolet radiation hazards. For this we takes as a standard the one which the American Conference of Governmental Industrial Hygienists (ACGIH) recommended with threshold limit values (TLVs) of UEI for exposure of eyes and skin.5) The Japanese Industrial Standard (JIS 8812) which has been revised recently also adopts the same standard for measurement of ultraviolet radiation. ${ }^{6)}$ The UEI based on the URSE recommended by ACGIH will be referred to by the term, "UEIACGIH", in the present paper.

In this study, the UEI approximately based on the URSE recommended by

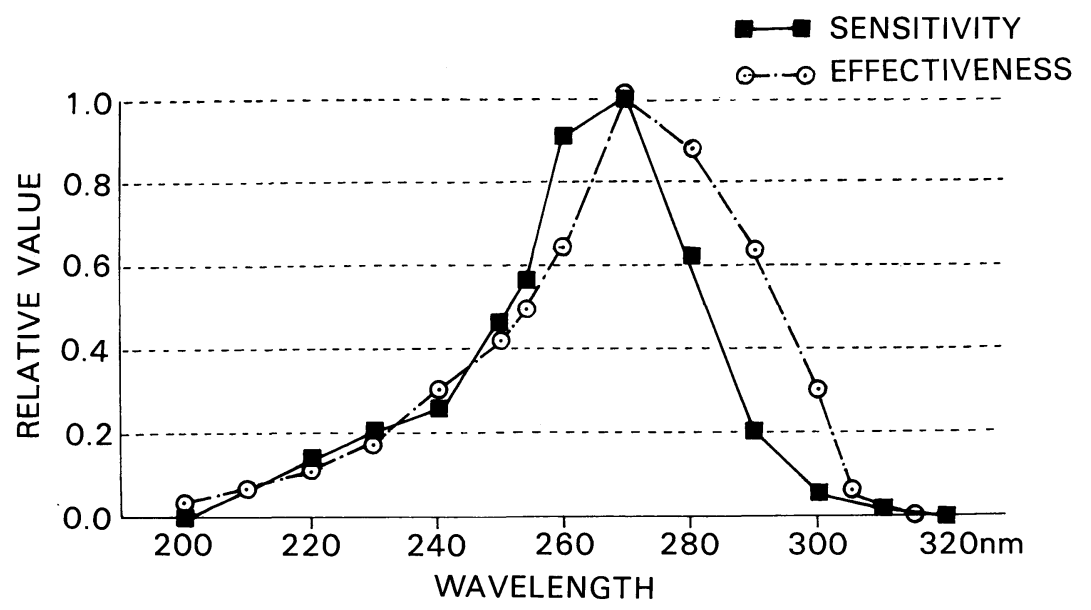

Fig. 1. Relative spectral sensitivity of the ultraviolet-radiation meter.

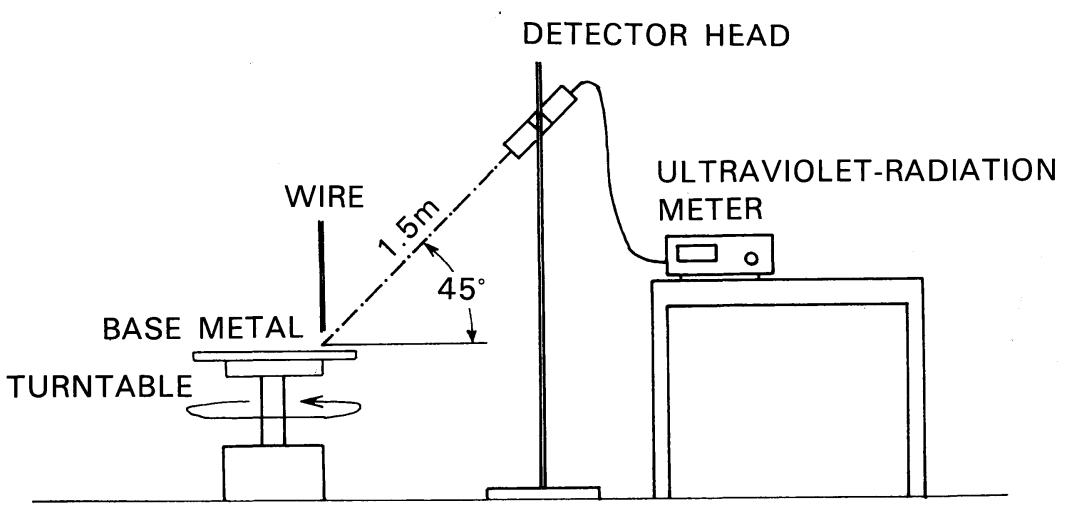

Fig. 2. Measurement configuration. 
ACGIH was determined for 14 different arc-welding operations commonly conducted in the workplace. The relation between the UEI and welding conditions was analyzed together with a problem regarding the measuring instrument used in this study. Besides the 14 arc-welding operations, in a preliminary experiment we measured gas welding with a gas mixture of oxygen and acetylene and plasma cutting with the same instrument. This showed that their UEI was negligible (less than $0.1 \mu \mathrm{W} / \mathrm{cm}^{2}$ at a distance of $5 \mathrm{~m}$ from the flame).

The measurement in this study was made simultaneously with that of emission spectra (spectral irradiance) and blue-light effective radiance, as reported in reference (3) and (4), respectively. Table 1 (welding conditions) in the present paper is almost the same as the corresponding table in reference (3) and (4), and Fig. 2 (measurement configuration) is a modification of the corresponding figure in reference (4).

\section{Method}

The UEI was measured for the 14 different welding operations shown in Table 1. For convenience of description, each operation is subsequently referred to by the number or symbol in the left-hand column. These welding operations were conducted as they are actually done in the workplace, except for No. 10, TIG welding, where a filler metal was not used in order to simplify the experimental setup. The details of the welding operations are described in reference (3).

The ultraviolet-radiation meter used to measure UEI was a model UV-3 of Sibata Scientific Technology Ltd.. Its relative spectral sensitivity as measured by the manufacturer before this experiment is shown with the URSE recommended by ACGIH in Fig. 1. If the former precisely coincided with the latter, we could measure the exact UEI-ACGIH with this measuring instrument. But there is a difference between them, as shown in Fig. 1, which is technically unavoidable with this type of measuring instrument, so this instrument gives us approximate values only. The influence of this difference on measured values will be discussed later. This ultraviolet-radiation meter indicates numerically the UEI accumulated in a given exposure time (measuring time). The average UEI in the exposure time can be obtained by dividing the indicated value by the exposure time in minutes and multiplying by $0.10 \mu \mathrm{W} / \mathrm{cm}^{2}$. That is, $1 \mathrm{cpm}$ (count per minute) equals $0.10 \mu \mathrm{W} / \mathrm{cm}^{2}$.

The measurement configuration is shown schematically in Fig. 2. An arc is struck and maintained between the fixed wire and the moving base metal on a turntable during measurement in order to fix the arc point, as detailed in reference (3). The detector head of the ultraviolet-radiation meter is set at $45^{\circ}$ from the horizon and at $1.5 \mathrm{~m}$ from the arc. Its detecting surface is aimed at the arc.

For each welding operation, 2 to 11 sets of measurement were made; one set 
consists of four to six successive measurements (exposure time 6 seconds each). Each set was started after experts on welding had made visually sure that the arc had been struck normally and had become stable and suitable for welding. The experimental and instrumental background was obtained in the same manner, except the welding arc was not struck, immediately before the start of each set of measurements. For all the sets, however, it was less than $1 \mathrm{cpm}$ and was neglected in the end.

\section{Results}

The two figures for each welding operation in the column of UEI in Table 2 show the average (upper) and the coefficient of variation (lower) in percentages, i.e., the quotient of the standard deviation divided by the average, of 2 to 11 sets of measurement. The UEI in this table is measured at $1 \mathrm{~m}$ from the arc; it was calculated from the measured value, assuming the inverse-square law.

Table 2. Results

\begin{tabular}{|c|c|c|c|c|c|}
\hline No. & Welding process & $\begin{array}{l}\text { UEI at } 1 \mathrm{~m} \\
\text { from arc } \\
\left(\mu \mathrm{W} / \mathrm{cm}^{2}\right) \text {, } \\
\text { Coefficient of } \\
\text { variation }(\%)\end{array}$ & $\begin{array}{l}\text { Correc- } \\
\text { tion } \\
\text { factor }\end{array}$ & $\begin{array}{c}\text { UEI- } \\
\text { ACGIH } \\
\text { at } 1 \mathrm{~m} \\
\text { from arc } \\
\left(\mu \mathrm{W} / \mathrm{cm}^{2}\right)\end{array}$ & $\begin{array}{c}\text { Permissible } \\
\text { exposure } \\
\text { time } \\
\text { per day } \\
\text { (sec) }\end{array}$ \\
\hline $1 \mathrm{a}$ & $\begin{array}{l}\text { Shielded metal arc welding } \\
\text { of mild steel, ilmenite type }\end{array}$ & 25.1 & $* 1.1$ & $* 10$ & *300 \\
\hline $1 b$ & $\begin{array}{l}\text { Shielded metal arc welding } \\
\text { of mild steel, ilmenite type }\end{array}$ & $\begin{array}{l}54 \\
13\end{array}$ & $* 1.1$ & $* 59$ & $* 51$ \\
\hline $1 \mathrm{c}$ & $\begin{array}{l}\text { Shielded metal arc welding } \\
\text { of mild steel, ilmenite type }\end{array}$ & $\begin{array}{l}82 \\
26\end{array}$ & $* 1.1$ & $* 90$ & $* 33$ \\
\hline $2 b$ & $\begin{array}{l}\text { Shielded metal arc welding } \\
\text { of mild steel, low-hydrogen type }\end{array}$ & $\begin{array}{l}76 \\
17\end{array}$ & $* 1.1$ & $* 84$ & $* 36$ \\
\hline $2 \mathrm{c}$ & $\begin{array}{l}\text { Shielded metal arc welding } \\
\text { of mild steel, low-hydrogen type }\end{array}$ & $\begin{array}{r}160 \\
27\end{array}$ & $* 1.1$ & $* 180$ & $* 17$ \\
\hline 3 & $\begin{array}{l}\mathrm{CO}_{2} \text { welding of mild steel } \\
\text { with solid wire }\end{array}$ & $\begin{array}{r}120 \\
8\end{array}$ & 1.1 & 130 & 23 \\
\hline 4 & MAG welding of mild steel & $\begin{array}{r}190 \\
39\end{array}$ & 1.1 & 210 & 14 \\
\hline 5 & $\begin{array}{l}\mathrm{CO}_{2} \text { welding of mild steel } \\
\text { with solid wire }\end{array}$ & $\begin{array}{r}170 \\
23\end{array}$ & 1.1 & 190 & 16 \\
\hline 6 & MAG welding of mild steel & $\begin{array}{r}550 \\
41\end{array}$ & 1.1 & 610 & 4.9 \\
\hline 7 & $\mathrm{CO}_{2}$ welding of mild steel & $\begin{array}{r}130 \\
23\end{array}$ & $* 1.1$ & $* 140$ & *21 \\
\hline 8 & $\begin{array}{l}\mathrm{CO}_{2} \text { welding of stainless steel } \\
\text { with flux-cored wire }\end{array}$ & $\begin{array}{l}87 \\
10\end{array}$ & $* 1.1$ & * 96 & *31 \\
\hline 9 & MIG welding of aluminum & $\begin{array}{r}300 \\
64\end{array}$ & 1.4 & 420 & 7.1 \\
\hline 10 & TIG welding of stainless steel & $\begin{array}{l}11 \\
15\end{array}$ & $* 1.1$ & $* 12$ & $* 250$ \\
\hline 12 & Self-shielded arc welding & $\begin{array}{l}59 \\
15\end{array}$ & & & \\
\hline
\end{tabular}

* Estimated value 
The obtained UEI is based on the relative spectral sensitivity of the ultravioletradiation meter and is generally different from the exact UEI-ACGIH, as mentioned before. The correction factor in the table is the ratio between them, that is, the UEI-ACGIH can be calculated by multiplying the UEI by the correction factor for each welding operation. The correction factor $F$ is defined by the following equation for the ultraviolet radiation whose relative spectral irradiance (relative emission spectrum) is represented by $I(\lambda)$, a function of wavelength $\lambda$.

$$
F=\frac{\int_{200 \mathrm{~nm}}^{315 \mathrm{~nm}} I(\lambda) \cdot S(\lambda) d \lambda}{\int_{200 \mathrm{~nm}}^{320 \mathrm{~nm}} I(\lambda) \cdot S_{0}(\lambda) d \lambda},
$$

where $S(\lambda)$ is the URSE recommended by ACGIH and $S_{0}(\lambda)$ is the relative spectral sensitivity of the ultraviolet-radiation meter (Fig. 1). Since the relative spectral irradiance in the ultraviolet wavelength region was obtained, ${ }^{3)}$ for welding operations, Nos. 3-6 and No. 9, a correction factor can be calculated by doing the integrations in Eq. 1 numerically. Nos. 3-6, which are $\mathrm{CO}$. or MAG welding of mild steel, have a correction factor of 1.1 in common, since they have almost the same relative spectral irradiance. ${ }^{3)}$ For the other operations, since relative spectral irradiance in the ultraviolet region was not obtained, a correction factor is unobtainable. But, except for the No. 12 self-shielded arc welding, a correction factor is estimated to take the same value 1.1 as Nos. 3-6 take in common because those welding operations, whose welding material is all mild or stainless steel, have almost the same relative spectral irradiance in the visible region as Nos. $3-6^{3)}$ and probably also in the ultraviolet region. These estimated correction factors are also entered in Table 2 with an asterisk.

The UEI-ACGIH in Table 2 is the product of the UEI multiplied by the corresponding calculated or estimated correction factor. From this the permissible exposure time per day in the table was calculated according to the recommendation of the ACGIH. ${ }^{5)}$ It is obtained by dividing $3 \mathrm{~mJ} / \mathrm{cm}^{2}$ by the corresponding UEI-ACGIH. The UEI-ACGIH and the permissible exposure time which were derived using the estimated correction factor are indicated by an asterisk. It should be noted that the UEI-ACGIH and permissible exposure time in the table, as well as the UEI, are measured at $1 \mathrm{~m}$ from the arc.

\section{Discussion}

Most of the obtained permissible exposure times per day in Table 2 range from several seconds to one minute. This indicates that the ultraviolet radiation is at a hazardous level for both those who conduct welding operation and those who work near it for the following reasons.

For welders, since they usually take their position at a distance of several tens of centimeters from the arc, the UEI-ACGIH they are exposed to would be several 
times higher than that in Table 2 , which is at $1 \mathrm{~m}$, and the permissible exposure time for them also would be shorten to a few tenths, probably less than 10 seconds. But, their exposure during welding operation can be neglected if welders use ordinary filter glass, because its transmittance in the ultraviolet wavelength region is normally less than $10^{-4} \%$ and the permissible exposure times would increase by more than $10^{6}$ times. The direct exposure of welders at the time of striking an arc is more important. Generally, welders' filter glass is so dark that with the arc off, nothing can be seen through it. Therefore, when starting welding, welders make sure with the unprotected eye that the arc strikes at an appropriate point and then put on the filter glass. Though the exposure time in that interval is short, if a welder strikes an arc more than several times a day, his added exposure time in the day must easily exceed the permissible exposure time of several seconds.

The ultraviolet radiation from the welding operations in this experiment is at a hazardous level for those who work near a welding arc, as well as for welders. Assuming that they are usually several meters away from a welding arc, the UEI-ACGIH they are exposed to is lower than that in Table 2 and the permissible exposure times for them is longer. But it is still as short as one to several minutes and their added exposure time in a day would be likely to exceed it.

In order to prevent the exposure to the ultraviolet radiation at the start of welding, it is advisable for welders to use, beside the ordinary one, another filter glass which is transparent or light enough for welders to see through it with the arc off but cuts out all the hazardous ultraviolet radiation. A plate of ordinary glass (soda-lime glass) would serve this purpose. If welders always wear it and put on ordinary filter glass over it after striking an arc, they are exposed to no ultraviolet radiation.

In the welding operations in this experiment, there are several groups: the group of shilded metal arc welding of the ilmenite type (Nos. 1a, 1b and 1c), that of the low-hydrogen type (Nos. $2 b$ and $2 c$ ), the group of $\mathrm{CO}_{2}$ welding with solid wire (Nos. 3 and 5) and that of MAG welding (Nos. 4 and 6). In these the type of welding method and the chemical composition of the welding material are common but the diameter of wire, arc current and arc voltage vary. These parameters are not independent. The latter two generally increase with the former under optimum welding conditions. In those groups, both the UEI and the UEI-ACGIH clearly increase with these parameters. In order words, the ultraviolet radiation hazards increase with the consumed electric power for the same welding, as might be expected. But, in all the welding operations in this experiment, the UEI or UEI-ACGIH is not correlated with the arc current, arc voltage or their product (electric power). This indicates that the type of welding method itself is one of the most impotant factors determining the ultraviolet radiation, as are the diameter of wire, arc current and arc voltage.

Making a comparison among Nos. 1a-8, which are all welding of mild or stainless steel, it seems in general that the UEI-ACGIH for the welding without 
flux (Nos. 3-6) is higher than that using wire coated with flux (Nos. 1a-2c) or using flux-cored wire (Nos. 8 and 9). It is difficult to think that the substances contained in the flux or the products which might be generated from them in the arc absorb ultraviolet radiation strongly, because the welding operations with and without flux differ too little in relative spectral irradiance. ${ }^{3)}$ More probably the flux which is scattered in the air around the arc during welding operation intercepts the ultraviolet radiation geometrically.

TIG welding, No. 10, has the second lowest UEI-ACGIH of all the welding operations in this experiment. Apparently the quantity of iron in the arc, whose light emission accounts for the greater part of the optical radiation from the arc for the other welding operations of mild or stainless steel, is small because no filler metal is used. ${ }^{3)}$ In the workplace, TIG welding, which is conducted always with filler metal, must emit intenser ultraviolet radiation.

The UEI for No. 12, self-shielded arc welding, is relatively low compared with its arc current and arc voltage. This is apparently the effect of Rayleigh scattering by a large amount of the generated fumes, judging from its relative spectral irradiance. $^{3)}$

MIG welding, No. 9, is the welding of aluminum alloy containing 4-5\% magnesium, unlike the other welding operations in this experiment which involve mild or stainless steel. Here the UEI-ACGIH is relatively high compared with its arc current and arc voltage. This indicates that the light emission from magnesium which constitutes almost all the ultraviolet part of the spectral irradiance of No. $9^{2,3)}$ is considerably intense. Moreover, since the visible part of the spectral irradiance is much weaker than the ultraviolet part, ${ }^{3)}$ the arc is more hazardous to see than might be imagined from its brightness. Though experimental data for welding of aluminum are insufficient, it may be that the welding of aluminum generally emits intenser ultraviolet radiation than that of mild or stainless steel.

Finally, let us consider the ultraviolet-radiation meter used in this experiment. It was produced for the purpose of measuring UEI-ACGIH. But it indicates not exact but approximate UEI-ACGIH because of the small disagreement between its relative spectral sensitivity and the URSE recommended by ACGIH. In this experiment, the spectral measurement was made simultaneously, ${ }^{3)}$ and the measured UEI was corrected using the results for some of the welding operations. But when we measure the ultraviolet radiation from various sources in the workplace with this ultraviolet-radiation meter, we must do without such a correction, because it is generally quite difficult to make spectral measurement in the workplace. Therefore, the degree of the deviation of masured value from the exact UEI-ACGIH is of great concern. It depends on the relative spectral irradiance of the radiation to be measured. For instance, Nos. 3 to 6 in this experiment, which are $\mathrm{CO}_{2}$ or MAG welding of mild steel, have almost the same relative spectral irradiance ${ }^{3}$ (Fig. 3) and have a correction factor of 1.1 in common. 


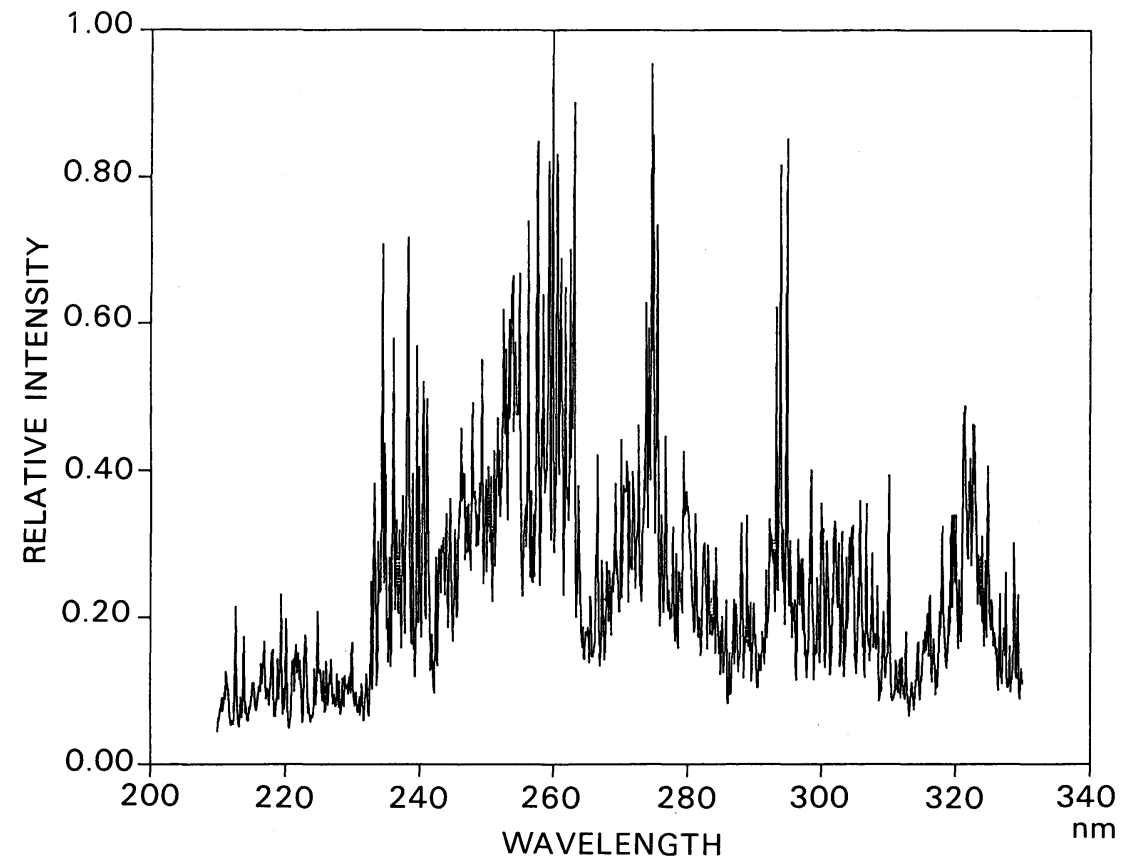

Fig. 3. Ultraviolet relative spectral irradiance of No. 6, MAG welding of mild steel.

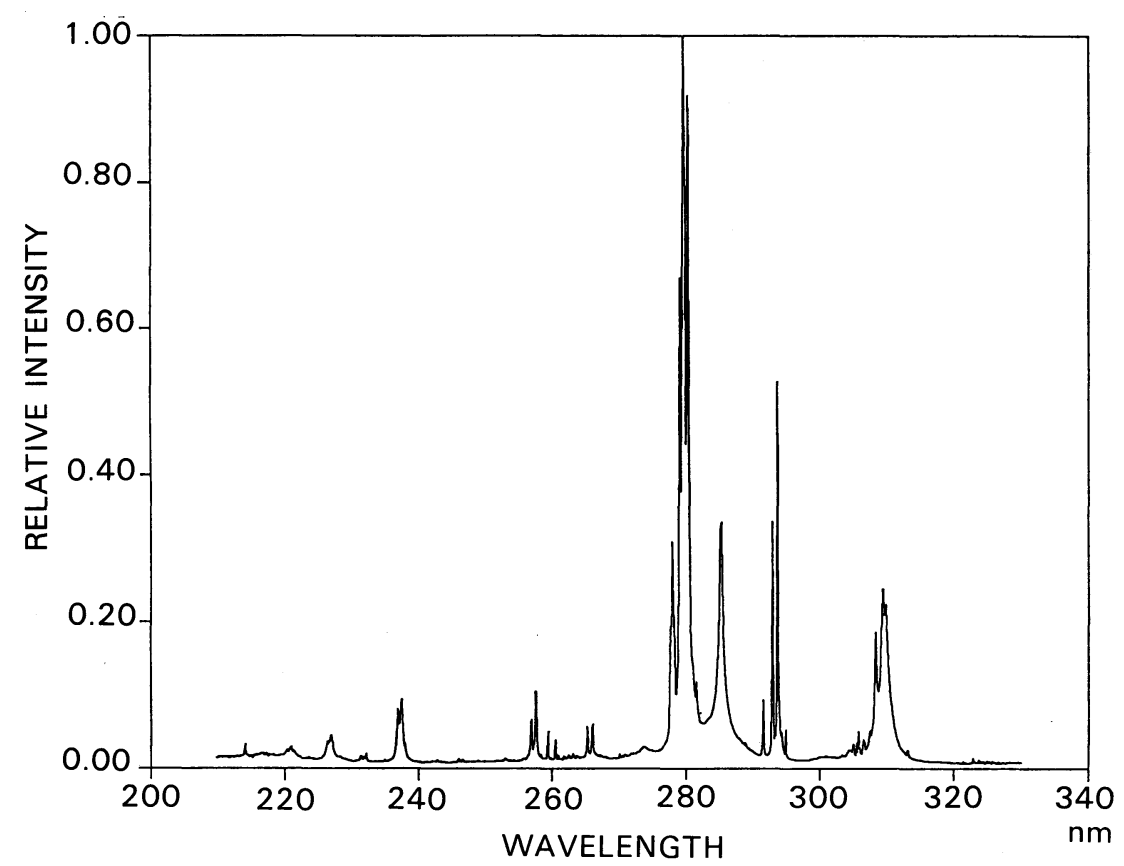

Fig. 4. Ultraviolet relative spectral irradiance of No. 9, MIG welding of aluminum. 
This means that the deviation of measured values is $10 \%$ for these welding operations. This would be practically permissible, compared with the coefficients of variation obtained for them, 8-41\% (Table 2). On the other hand, the relative spectral irradiance of No. 9, MIG welding of aluminum ${ }^{3)}$ (Fig. 4), is quite different from that of the above welding operations, and its correction factor is as large as 1.4. So the ultraviolet-radiation meter underestimates ultravioletradiation levels by $40 \%$. Therefore, it is dangerous to accept measured values unconditionally for this welding. It is concluded that the ultraviolet-radiation meter used in this study is applicable to the measurement of radiation in which the intensity is distributed widely in the ultraviolet spectrum, as in Fig. 3, but is unsuitable for measuring radiation in which the intensity is localized around only several wavelengths, as in Fig. 4.

\section{ACKNOWLeDGMENT}

The author acknowledges the continuing guidance and encouragement of Dr. S. Koshi. He also would like to express his appreciation to Mr. T. Myojo.

\section{REFERENCES}

1) The Japan Welding Engineering Society. Ultraviolet Emissions in Welding, Transmissions of Safety Glasses, and Eye Hazards of Welders. 1979.

2) Bartley DL, McKinnery WN, Wiegand KL. Ultraviolet emissions from the arc-welding of aluminum-magnesium alloys. Am Ind Hyg Assoc J 1981; 42: 23-31.

3) Okuno T. Spectra of Optical Radiation from Welding Arcs. Ind Health 1985; 23: 53-70.

4) Okuno T. Measurement of Blue-Light Effective Radiance of Welding Arcs. Ind Health 1987; 24: 213-26.

5) American Conference of Governmental Industrial Hygienists. THRESHOLD LIMIT VALUES and BIOLOGICAL EXPOSURE INDICES for 1986-87. 1986; 104-6.

6) Japanese Standard Association. JIS Z8812-1984 Measuring Methods of Eye-hazardous Ultraviolet Radiation. 